\title{
Congreso Internacional de Hans Urs von Balthasar. La cuestión del ser 23-26 de septiembre de 2008
}

Si bien es difícil sintetizar la riqueza, intensidad y profundidad del Congreso Internacional Hans Urs von Balthasar, celebrado del 23 al 26 de septiembre de 2008, resulta significativo destacar algunos aspectos relevantes de un esfuerzo inusitado en nuestra Facultad, es decir, "pensar juntos" la cuestión del ser durante cuatro días. Los frutos desbordan nuestras expectativas, tanto en lo que se refiere a la calidad de las ponencias, expuestas por numerosos especialistas internacionales y nacionales, cuanto a la acogida atenta de parte de un público, sorpresivamente, especializado en diferentes áreas del saber humano, que se hizo presente en el Aula Magna de la Facultad de las Ciencias Económicas -lugar muy adecuado para una escucha prolongada silenciosa, aunque rodeado por el bullicio estudiantil del Campus San Joaquín. No cabe duda, que tal experiencia singular sólo fue posible gracias al intenso trabajo en red a full time de la misma Facultad, que no interrumpió la seriedad del quehacer teológico cotidiano, pero sí se involucró a todo nivel con el Congreso, creando aquel clima humano, tan admirado por los profesores visitantes, que favorece desde dentro el pensar juntos.

Pese a que la figura central del Congreso fue el teólogo suizo, ya que la conmemoración del vigésimo aniversario de su muerte fue el motivo para celebrar el presente Congreso, las exposiciones abordaron el pensamiento de Balthasar, de tal forma que más que detenerse en análisis estériles de conceptos, lograron sacar a la luz los efectos de la historia de recepción -Wirkungsgeschichte- del pensamiento balthasariano, atestiguando así la grandeza de un pensador, que, en cuanto "hombre más culto del siglo XX”, es considerado, junto con Karl Rahner, el teólogo más grande de nuestro tiempo. En efecto, la profundidad trinitaria originaria del ser, concretada en el deseo humano en cuanto expresión masculina analizada con nitidez por la comparación entre Balthasar y Octavio Paz, pero completada por la "sonrisa de Beatriz", magistralmente, dilucidada en la obra de Dante, fue modulándose de múltiples maneras con relativa claridad a través de las exposiciones, reacciones y preguntas planteadas, también en las interminables conversaciones de pasillo. Sin duda, hubo momentos cumbres, sobre todo, cuando la cuestión del ser se vio trastocada por la música de Mozart hacia aquel umbral, que permite entrar en "las tinieblas del saber por medio del no-saber, el misterio de Dios. Pero no faltaron manifestaciones de desconcierto ante la forma cómo Balthasar aborda la estética, ni tampoco se callaron las voces críticas ante un posible descuido de la dimensión humana, siendo tan fuerte el impacto de la Gloria de Dios, de Su Bondad y Verdad. Sorprendieron, sin duda, las aproximaciones fenomenológicas, es decir, la comparación entre Husserl y Balthasar, por su originalidad y acierto, pero fueron primordialmente los aportes cristológicos trinitarios desde una perspectiva de San Juan, Ireneo, Orígenes, Gregorio de Nisa y Agustín, que hicieron transparentes las honduras de la pregunta por el ser, pero también la importancia decisiva de su comprensión e interpretación concretas. 
De cara a lo vivido y experimentado durante estos días, cabe recordar qué difícil es ganar un Proyecto FONDECYT, pero tal esfuerzo tiene su recompensa: el Congreso abrió posibilidades insospechadas.

Anneliese Meis 